\title{
1 Labour unionism and neo-liberalism
}

\section{Gregor Gall, Richard Hurd and Adrian Wilkinson}

\section{INTRODUCTION}

The widely televised and subsequently reported upon 'Battle of Seattle', a large scale conflagration at the scene of the World Trade Organization meeting in 1999, has become known for the 'unity of the Teamsters and the turtles' in opposing neo-liberalism. This epithet signified the hitherto unknown alliance of organised labour - labour unions ${ }^{1}$ - with the environmental protection movement. To the wider public throughout the world, this must have seemed like the first major, visible act by organised labour against not just the effects (or symptoms) of neo-liberalism but also in a sense their cause too (in terms of the global institutions associated with neo-liberalism). However, there are a number of paradoxes involved here. First, while organised labour's policy and ensuing behaviour towards neo-liberalism have developed and expanded since 1999, the 'Battle of Seattle' was not organised labour's first foray into this arena. Rather, the 'Battle of Seattle' has a pre-history as well as a post-history and this is what we intend to explore and analyse in the chapters of this handbook. Second, and just as importantly, what is also vital to demonstrate and then explore is that such a high profile event as the 'Battle of Seattle' does not adequately portray the diversity of the range of labour union responses to neo-liberalism. For example, in the United States many major labour unions have willingly cooperated with the drive towards neo-liberalism, and within this context have sought to safeguard US workers' interests to the detriment of other workers elsewhere - even though or alongside the AFLCIO rhetorically opposing neo-liberalism since the mid-1990s. To the extent that other labour unions in the United States have opposed free trade and the Bush (2001-2009) administration's economic policies did not necessarily imply opposition to neo-liberalism per se but rather a certain type of neo-liberalism and its effects at a certain point in time. In other words, most US unions have operated within the confines of neo-liberalism without mounting an ideological or political challenge to it, effective or otherwise. Thus, this handbook will not just examine labour union opposition and resistance to neo-liberalism but also labour support for and acquiescence with neo-liberalism.

The term neo-liberalism is a relatively recent arrival to the lexicon of popular discourse, and is not an appellation which neo-liberals use to describe 
themselves. So our first task in this introductory chapter is to lay out a definition of neo-liberalism and to present an overview as to what the implications of this are for workers and for their labour unions. From here, we make an appraisal of their relative effectiveness. Then, we outline a schema for categorising and understanding the responses of labour unions to neo-liberalism. This is an aid to identifying and accounting for the variation in their responses, responses which are derived from an interaction of constituency of interests and ideology (forming the basis of intention to act or react) and played out through processes and outcomes with other actors (employers, states, NGOs and so on). Finally, we give an overview of the structure and content of the handbook, not so much by summarising what they do as individual chapters but rather what the sums of their parts represent.

\section{NEO-LIBERALISM}

Neo-liberalism is a contemporary ideology based on historical economic liberalism which favours a minimised role for the state and a maximised role for the market (the private business sector) in the belief that the market is: (a) the most efficient and equitable distributor of resources and rewards; (b) the best guarantor of economic growth; and (c) the most able protector of individual liberty. In other words, anything that 'crowds out the market' is an impediment to the realisation of these outcomes. In this vein, economic growth and higher living standards for citizens are seen as directly linked to neo-liberalism because economic liberty and freedom would lead to more capital investment and greater output. Equally important, economic freedom is viewed as a precursor to political democracy. Thus, the attainment of anything approximating to social justice or decent, civilised and humane living standards for the majority of citizens in each society is argued to be bound up with this process. In this sense, neo-liberalism is not the open repudiation of the pursuit of social justice and redistribution of wealth and resources for it is posed as the great leveller for all citizens, even if the spoils of growth are distributed on a very uneven basis as per the process of de facto trickledown economics.

Neo-liberalism is thus bound up in a language and discourse of markets, market efficiency, labour market flexibility, and consumer choice where risk is shifted from governments and corporations onto individuals. Therefore, its principal means of operation are privatisation, marketisation, liberalisation, deregulation, and reductions in state spending. Where it differs critically from classical economic liberalism of the era of Adam Smith and David Riccardo is that it no longer holds that price is determined by the labour theory of value, whereby price is to be constructed by the amount of labour time used to produce a good or service. Rather, price is determined by what the market will 
bear and what individuals are prepared to pay in terms of the laws of human desire and supply and demand. This change in value theory arose in the $1880 \mathrm{~s}$ with the rise of the Austrian school and the development of utility theory.

There is a sense that neo-liberalism, for good or for ill, has increasingly swept away all pre-existing forms of economic activity. While an exaggeration, part of this perspective is an erroneous conflation of neo-liberalism with globalisation, not least because globalisation arguably predates neo-liberalism even though neo-liberalism has a pedigree extending back before the establishment of the post-war settlement - and because there are many different types of globalisation (Guillen 2001), of which the neo-liberal version is only one, albeit now the dominant one. Indeed, one could think of better appellations such as globalised neo-liberalism or neo-liberal globalisation for the phenomenon with which this handbook is concerned. Nonetheless, an overview of the literature by Guillen (2001) stressed that such globalised forces like neo-liberalism should neither be regarded as omnipotent nor as omnipresent, not least because of the counter-pressures and trajectories led by nation states. Obvious examples would include Cuba, Venezuela, contra Argentina and Brazil in Latin America.

The wider point that also emerges here is that neo-liberalism is not predicated upon the decline of the power and authority of the nation state, but rather the use of the nation state by internal and external forces to promote and implement neo-liberalism for international institutions like the World Bank, the International Monetary Fund, the World Trade Organization et al., dating from the Bretton Woods era, as advocates and agents for neo-liberalism are insufficient in themselves to effectively promulgate neo-liberalism. Given the centrality of the nation state to the neo-liberal project, different outcomes should be expected because there are different traditions and the sociopolitical and economic geography of nation states vary. Contrasting Britain, France and Germany with each other or the United States with Canada in this regard underlines the point. However, whether such differences in the guise of a 'varieties of capitalism' perspective necessarily implies that there is greater similarity or dissimilarity, divergence or convergence between and among the nation states is a moot point. While there are clearly differences in methods of implementation and outcomes vis-à-vis neo-liberalism, it can also be the case that these are but variations on a (grand) theme. Thus, what is common to the economic and societal change across the nation states of the last few decades may outweigh in importance inter- and intra-nation state differences that have emerged and developed. Here, critical analysts, such as Callinicos (2009), Castells (1996) and Harvey (2005), have argued that not to recognise this kind of meta-picture perspective is not to see the proverbial wood for the trees. In other words, the whole is greater than the sum of the parts.

That said, the ascendency and now hegemony of neo-liberalism has its 
roots in the post-war economic and political crisis that dates from the late 1960s. Initially, this crisis was one of rising political resistance to the capitalist status quo often led by unions. By the mid-1970s, the crisis had become far more of an economic one with the end of the long boom, whereupon the postwar settlement was decided by the progenitors of what we now call neoliberalism to have been the cause of the problem rather than the workings of capitalism itself. Therein followed a battle between the forces of the right and the left to determine how best to respond to the crisis. Suffice it to say that the forces of the right - the neo-liberals - won to the extent that they colonised such a large part of the political spectrum that the centre of gravity of politics in toto shifted towards them. Social democracy and Keynesianism were cast in the role of guilty parties. So it was not just that right-wing neo-liberal governments gained power and implemented their agenda throughout many countries. Britain under Thatcher and the United States under Reagan and Bush are only the most obvious examples of this. It was also that social democracy - defined as the regulation of the market and its outcomes for the purposes of attaining social justice - was undermined to such an extent that even where (formerly) social democratic parties were elected to office, often as a reaction to openly neo-liberal governments, they too pursued neo-liberal policies. This was because social democracy had transmogrified into (contemporary) social liberalism which in the Anglo-American world was denoted as the 'third way' (Giddens 1998) between unregulated capitalism and socialism. Thus, many commentators felt that no matter the professed belief of social liberalism in social justice, the bowing down to the market meant that social justice came a very poor second to the primary goals of economic growth and market efficiency, and that in effect, what came to pass was only a slightly restrained form of neo-liberalism.

Putting together its hegemony - in its two guises of outright neo-liberalism and social liberalism - at the level of the nation state also allowed neoliberalism to mould the policy and work of the international regulatory institutions of the word economy, namely the International Monetary Fund, the World Bank and the World Trade Organization, and their many regional counterparts. The consequences of this were the erosion and elimination of barriers to the movement of capital and goods (and sometimes labour) between nation states, as well as absolute and relative reductions in social welfare spending. Such influence at international, regional and national levels was cemented by the implosion of the state capitalist ${ }^{2}$ regimes of the Soviet Union and eastern Europe by 1990, and the endorsement and expansion of the market in China from the 1990s. Around this time, the term 'globalisation' entered the popular lexicon. In a further show of the influence of neo-liberalism, globalisation meant neo-liberal globalisation as opposed to globalisation imbued with social justice or (progressive) social revolution. Among the most obvious experi- 
ments in nation-state based neo-liberalism have been Australia, Britain, Canada, Chile, Japan, Mexico, New Zealand, Russia, Sweden, South Africa and the United States. This brief list indicates that neo-liberalism has captured the political high ground in an array of economies which have different historically dominant values and paths.

Harvey (2005) argued that neo-liberalism is a global capitalist class power restoration project. This line of argument stipulates that the political resistance of the 1960s and 1970s heightened the awareness of the ruling elites that a relative transferral of wealth and power from the employers to workers had taken place during the long boom, and that a resuscitation of profit levels in a period of economic contraction required the reduction of the workers' share of national wealth through the intensification and extensification of the wageeffort bargain. In other words, the rate of exploitation of workers was required to increase through intensifying their productivity and output within their existing hours of work, and extending their hours of work and thus their overall productivity and output. The ability to do this necessarily also required indeed, comprised - the restoration of the economic and political power of the ruling class on a global basis. Put more simply, neo-liberalism was the response of the ruling elites to the economic and political crisis. Before moving on to examine the implications of the enforced advance of neoliberalism upon workers and their organs of collective representation, it is worth noting that the economic and political crisis of neo-liberalism of the early part of the twenty-first century has not witnessed the resurgence of Keynesianism, the regulation of markets or of social democracy. State intervention has been used to support and reinforce market mechanisms (at the expense of cutbacks in public expenditure to service the national debts incurred to do so) rather than reduce or expunge the extent of market mechanisms. Economically and politically, neo-liberalism has emerged relatively unscathed from this crisis because of the palpable inability of the left to challenge the dominant ideological narrative. The only part of the global economy where neo-liberalism has been successfully and effectively challenged to date, albeit still within a global framework of neo-liberalism, has been in a number of economies in Latin America. Venezuela is the most obvious example here (Gott 2001, 2005). The case of South Africa, it seems, is one where the potential to realise such opposition to neo-liberalism under the ANC-COSATUCPSA alliance since the ending of apartheid in 1994 has not come to fruition, as the ANC has marginalised its former leftist allies and become a home for advocates of a version of African neo-liberalism. In regard of China, the state still maintains a considerable role in organising, directing and constituting the economy so that the impact of neo-liberalism is significantly blunted. The issue of which groups in Chinese society benefit from this maintained state role and to what degree is a point of considerable debate. 
The import of this brief discussion has been to emphasise the encompassing, if not quite all encompassing, nature and strength of neo-liberalism as a political force. For workers and labour unions, outright neo-liberalism and its social liberal variant have been equally important. Neo-liberalism here can be viewed as dangerous and pernicious. This is either because it is a deliberate and conscious subterfuge for the project of the transferral of wealth and power to existing political and economic ruling elites, where there is a redistribution of wealth away from the poor and towards the rich, or because despite the intentions, the processes and results of actual neo-liberalism serve to lead to this outcome as existing economic elites seize the opportunities to achieve such an outcome. However, social liberalism has in one sense been even more pernicious for it has colonised the main organs of political representation upon which labour unions have traditionally relied, in the process not only robbing unions of that political representation but also disorientating them. This has made the task of attempting to resist neo-liberalism more challenging and difficult.

\section{WHAT NEO-LIBERALISM MEANS FOR WORKERS}

At base, when implemented neo-liberalism means the greater direct exposure of workers to vagaries of the market and to the ability of employers to intensify and extensify the wage-effort bargain in their own favour. Furthermore, neo-liberalism is associated with reduced protection for workers in the form of state actions to regulate and modify market outcomes, and thus there is a reduced ability for workers to act collectively in defence of their interests through legal and quasi-legal means. Moreover, human resource management, whether in its hard or soft versions, can be viewed as the application of neoliberalism in the workplace. Of course, there is an array of forms which this collective scenario can take, varying across time and space. Flexible work organisation and working-time and employment practices where the flexibility is tilted towards the employer are some of the most obvious means. Examples are deskilling, zero-hour contracts, and self-employment respectively. It is not the case that there is a single way in which neo-liberalism has operated and been implemented whether at the level of the workplace or the enterprise. In Britain and the United States, for example, leveraged buyouts (including the use of private equity) seem more common than elsewhere possibly reflecting the relatively less regulated financial and economic regimes within these economies which facilitate this phenomenon - whereby massive debt is run up to take over another company by the acquisitor. This, over and above the search for profits, increases the pressure to slash and burn in order to service and pay off the incurred debt. The most obvious targets are the jobs and terms and conditions of workers. Labour costs not only represent 
a large proportion of operating costs, they can also be used as shock absorbers when other costs are outside the control of employers.

The greater exposure of workers to the vagaries of the market and the interests and power of employers is the direct result of the reduction in state intervention in the market - whether in terms of social wages funded, in part, through corporate taxation, the terms of minimum wages and pension provision through enforced obligations upon employers, or other forms of regulation of the employment relationship. Indeed, in many cases states have gone further by not only allowing labour and capital to self-regulate their relationship - which almost always means allowing capital to dominate - but also intervening on the side of capital to restrict the ability of organised labour to aggregate its forces. This is most evident in the regulation of industrial action and strikes.

The battle cry of neo-liberalism has been to tear down any barriers that impede labour market flexibility and that constitute so-called 'labour market rigidities'. Reduced labour market regulation and reduced regulation of the employment relationship have increased freedom for employers to act, but also has reduced regulation over capital movements and financial forms of capital. The two come together particularly sharply in the so-called 'race to bottom' where unionised workers are faced with the prospects either of ceding concessions from their hard won gains of collective bargaining, of moving to non-unionised workplaces working under worse conditions than before, or of seeing their jobs transferred to an area of lower labour costs (normally in another country but also possibly within countries). And the drive for profits means that capital will search for areas of lower labour costs than those which were previously the lowest, so creating the downward spiral.

However, greater exposure of workers to the vagaries of the market can also come about as the result of employers off-loading previous commitments to employees in terms of pensions, employment security and employability among others. For example, many employers have cut back on the worth and existence of pensions which are conventionally conceived as deferred wages, while outsourcing, particularly through using previously employed workers as selfemployed contractors, divests employers of many financial responsibilities. The rise of the notion of employability heralds a new era where it is the responsibility of already employed workers, not employers, to make sure that they are trained and skilled in the requisite needs for the employer's business demands.

Some may view neo-liberalism as just capitalism 'plain and simple' - or just another form of capitalism with its underlying dynamics unchanged. And, in this regard, the impact upon workers would be viewed as neither new nor surprising. (Indeed, every technique deployed in the service of the greater exploitation of workers under neo-liberalism can be found to have an antecedent in pre-neoliberal times of the late 1970s onwards or a prior parallel.) And while there is some truth in this, such a perspective would, nonetheless, downplay the specific 
importance of the neo-liberal project as a means of refashioning and reconfiguring capitalism through a persuasive ideology and at a key point in human history as per the crisis of contemporary capitalism after the long boom.

The implications for unions as collective organisations of workers in the workplace are equally grave. In the industrial arena, the rights to associate, to organise and to take industrial action have come under attack not only as lawful rights but also as effective rights through a combination of de jure and de facto restrictions. Consequently, in most, though not all, economies this has been one of the key factors - along with unemployment and associated job insecurity - in demobilising the ability of labour unions to respond effectively to the challenges from employers. Furthermore, as neo-liberal globalisation has marched on apace, the ability of unions to act internationally has been impeded by instances like those within the European Union where the right to take industrial action has been struck down by the judiciary because it is deemed to interfere with a higher right, namely that of companies to trade (see the Viking, Laval, Ruffert and Luxembourg judgments of European Court of Justice). Of course, it would be wholly wrong to give the impression that it is only external factors and processes that prevent a more robust response from labour unionism. That is clearly not the case and is testified to by the inability to develop effective forms on international labour unionism. Yet, it remains the case that this environment in which unions operate is a critical impediment to the success of achieving their goals.

\section{LABOUR UNION RESPONSES}

It can be judged from both the content and tone of the prior discussions of neoliberalism and its implications that labour union responses have been inadequate and ineffectual in the realms of ideas and actions. Whether that is to presuppose that different responses could be wholly adequate and effective given the scale of the challenge neo-liberalism represents is another matter. Nonetheless, and notwithstanding a few individual and small scale 'bright sparks' like organising immigrant workers in Los Angeles (Milkman 2006), the rebuilding of the RMT union as a militant body (Darlington 2009) or the effectiveness of the International Transport Workers Federation (Anner et al. 2006), labour and organised labour have suffered the blows of neo-liberalism and have been unable to construct an effective industrial or political counterresponse to turn back the tide. The proportion of enterprise operating costs accounted for by workers' labour costs has fallen leading to relative immiseration and degradation as, thus, has their share of the wealth generated through enterprises. Meanwhile in most western economies the influence of workers per se and through their unions within the enterprises has been diminished. 
The flipsides to these are that the proportion of wealth taken by managers, employers and shareholders has increased and dramatically so, while the right of management to (unilaterally) manage has been considerably reinforced and extended. This trajectory of ineffective forms and action of labour unionism is all the more noticeable on the international stage where international labour unionism is still woefully underdeveloped despite over one hundred and fifty years since the International Workingmen's Association was established (with the participation of Marx and Engels) and which recognised the need for this.

Setting aside the problems and issues of union developing and applying strategies, much less effective ones (see Gall 2011), and based on observation of existing practice, there are many broad categories of responses and reactions that labour unions could take towards neo-liberalism. Whether they are of the unions' own genuine volition, a result of extremely limited choices or grudgingly and reluctantly enforced upon unions is of some importance as well. The same is true of whether these are implicit or explicit assessments and whether unions make these at higher levels of abstraction such as the nationstate and world economy levels. Nonetheless, a rough categorisation would include the following.

The first could be termed agreement and support. Here, neo-liberal globalisation is viewed as benign or progressive, and unions and their members can benefit from it where the relevant companies, sectors or economies can successfully compete. This would be a mutual gains agenda and is the territory of some business-type labour unionisms in a number of advanced economies.

The second could be termed qualified and conditional support, where unions advocate that workers require sympathetic strategic state and suprastate action to provide protection for themselves and for their employers/ sectors/industries in order to compete fairly and successfully, as well as to protect themselves from the worst effects of globalisation and 'the race to the bottom'. Here, the language of simply wanting 'a level playing field' and the 'equality of opportunity' to compete are common, including state provision of educational and technological services to allow fair competition.

The third could be termed social democratic opposition, where unions believe in the policy and practice of opposition to corporate globalisation and advocate social democracy as an alternative in order to socialise, not abolish, the capitalist economy. Here, market processes and outcomes are moderated to ensure some semblance of equality of outcome in terms of attaining social justice whereby not all considerations are reducible to the single issue of enhancing profitability. One example of the pursuit of this approach at the global level is that of establishing international labour standards.

The fourth could be termed socialist resistance where unions believe in opposition and resistance in word and deed to capitalist globalisation, and advocate socialism on a national and global basis as the alternative. In this 
instance, the operation and role of the market would be greatly diminished or abolished so that need rather than profit became the guiding light of society.

In summary, the four positions could be labelled neo-liberalism, social liberalism, social democracy and socialism. In order to operationalise such categorisation, it is more helpful to see these four positions as poles of attraction on a spectrum ranging from right to left. Within this conceptualisation, unions, peak union organisations and union movements would be capable of shifting over time from one position to another in response to internal and external dynamics, as well as creating hybrids of those positions. Their respective positions would comprise ideologies, policies and actions primarily in the industrial and political arenas. The relative balance of power between unions, employers and the state, and the interplay of this in regard to how they perceive their interests, would be a major explanatory variable in unions deciding which of the four positions to adopt and their ability to prosecute this.

\section{CONTENT OF THE HANDBOOK}

The aim of this handbook is to provide an overview and assessment of union responses to neo-liberalism over the last thirty or so years. It will use the aforementioned four-fold framework to examine the key issues and important emerging trends within and across national union movements in an array of different countries. In this way, we hope that some fairly explicit threads can be seen to be running through this handbook. While there are other books in this field, they tend to focus on a single country, or a limited number of countries, or they may cover only a limited number of issues. There are also comparative books that examine one important issue, for example, the role, behaviour, influence and recent decline of unions within a particular trading region or across trading regions. We seek to combine these various facets but on a deeper and broader scale with regard to neo-liberalism and using the framework establish a common means for doing so. The handbook comprises introductory and reflective essays which are the outer coating and foundation stones for a larger number of country-based studies where contributors examine labour union responses. We are delighted to have contributions from Richard Trumka of the AFL-CIO and Bill Fletcher Jr of Center for Labor Renewal in the US. The handbook is primarily designed for academics and for students taking advanced courses in comparative employment relations. But the book is also intended to appeal to practitioners, interest groups and policy makers who have an interest in examining approaches to employment relations problems and issues that differ from their own national context. Inevitably, there are gaps in terms of the country studies, such that there are no chapters on Brazil, Canada, Japan and Mexico, for example. This is always 
the case where space is limited. Nonetheless, we hope that the range and scope of the chapters is sufficient to provide a basic foundation in understanding the 'how', 'when', 'why' and 'where' of union responses to neo-liberalism. Unfortunately, no chapter has been able to identify the magic panacea with which unions can turn back the tide of neo-liberalism and return to some progressive form, at least, of fundamental market regulation. That book is still waiting to be written but it would be a sweet point if the emerging battles in Wisconsin, Ohio and Indiana in early 2011 played a role in allowing this.

\section{ACKNOWLEDGEMENTS}

We thank all our contributors for their acceptance to write their chapters. Much of the editing of this handbook was carried out while Gregor Gall was in receipt of a Sir Allan Sewell Fellowship at Griffith University, Australia. $\mathrm{He}$ is grateful for the opportunity afforded by this.

\section{NOTES}

1. Most unions are no longer either trade unions or unions of trades despite the continued widespread usage of the term by writers. Rather, they are - certainly by membership coverage increasingly general and industrial unions. Thus, we use the terms 'labour unions' and 'labour unionism' because this more appropriately and accurately focuses upon the fundamental aspect of unions as collective bodies of labourers whose organisational raison d'être is, at the very least, regulating the wage-effort bargain. To the extent that unions remain as specialist unions, these are more commonly occupational unions, occupation being a wider construct than 'trade'.

2. These regimes of 'actually existing socialism' are better approximated to by the concept of state capitalism, whereby an elite controlled - and benefited from - the extraction of surplus labour from the majority of the populaces.

\section{REFERENCES}

Anner, M., I. Greer, M. Hauptmeier, N. Lillie and N. Winchester (2006), 'The industrial determinants of transnational solidarity: global inter-union politics in three sectors', European Journal of Industrial Relations, 12(1) 7-27.

Callinicos, A. (2009), Imperialism and Global Political Economy, Cambridge: Polity Press.

Castells, M. (1996), The Rise of the Network Society - The Information Age: Economy, Society and Culture, Vol. 1, Oxford: Blackwell.

Darlington, R. (2009), 'Leadership and union militancy: the case of the RMT', Capital and Class, 98, 3-32.

Gall, G. (2011), 'Union strategy and circumstance: back to the future and forward to the past?', in K. Townsend and A. Wilkinson (eds), Research Handbook on Work and Employment Relations, Cheltenham, UK and Northampton, MA, USA: Edward Elgar.

Giddens, A. (1998), The Third Way: the renewal of social democracy, Cambridge: Polity Press. 
Gott, R. (2001), In the Shadow of the Liberator: the Impact of Hugo Chávez on Venezuela and Latin America, Verso: London.

Gott, R. (2005), Hugo Chávez and the Bolivarian Revolution, Verso: London.

Guillen, M. (2001), 'Is globalization civilizing, destructive or feeble? A critique of five debates in the social science literature', Annual Review of Sociology, 27, 235-40.

Harvey, D. (2005), A Brief History of Neo-liberalism, Oxford: Oxford University Press.

Milkman, R. (2006), LA Story: Immigrant workers and the future of the US labor movement, New York: Russell Sage Foundation. 